https://doi.org/10.5817/OS2021-3-6

\title{
Коллоквиум Београд-Брно, 2021. Савремена српска и чешка славистичка истраживања
}

Коллоквиум «Београд-Брно» является одной из форм сотрудничества между Кафедрой славистики филологического факультета Белградского университета и Институтом славистики философского факультета Университета им. Масарика в Брно. Традиция проведения данного мероприятия каждые два года появилась в 2006 году, когда инициаторами создания коллоквиума для поддержания научного диалога в области славистики стали проф. Боголюб Станкович, проф. Иво Поспишил, а также проф. Петар Буняк. Теперь это событие, несомненно, затрагивает большее количество заинтересованных исследователей, преподавателей и студентов.

В 2021 году коллоквиум получил тему и название «Савремена српска и чешка славистичка истраживања» и состоялся в четверг, 21 октября. На мероприятии было прочтено 19 докладов, и отличительной чертой этого коллоквиума стало то, что выступления участников касались не только области лингвистики, но и литературы, кино, художественного искусства, музыки, истории и чешско-сербских взаимоотношений.

Программа коллоквиума была действительно насыщенная и состояла из пленарного заседания и четырех блоков. Мероприятие открывал вводный доклад проф. Иво Поспишила, в котором поднимался важный вопрос о необходимости и перспективах развития компаративистики как науки, что связано с расширением взаимовлияний культур, процессами стирания границ между национальными культурами и, соответственно, их литературами.

Большую полемику в рамках первого блока вызвал доклад проф. Йозефа Догнала, который говорил о мере ознакомления студентов-русистов с культурой, историей, литературой и искусством. В ходе дискуссии был поднят вопрос о том, что уровень знаний студентами социокультурных и исторических реалий с каждым годом падает, а также о том, что учащиеся не всегда оказываются способными самостоятельно находить информацию. Возник вопрос: как обучить студента так, чтобы он обладал необходимыми знаниями, умениями и навыками, требуемыми от выпускника университета? Обмен опытом и мнениями, активная дискуссия показали, что эта проблема действительно оказалась важной для всех участников мероприятия.

Необходимыми для раскрытия проблематики коллоквиума оказались доклады, касающиеся изучения чешско-сербских отношений. Таковыми были, например, рассказ доц. Вацлава Штепанека о чехах и сербах из австро-венгерских земель 
в Первой сербской добровольческой дивизии на фронте в Добрудже; или выступление доц. Александры Корды-Петрович об истории сербско-чешских культурных корней.

Многие доклады коллоквиума представляли собой анализ некоторой лексики чешского, сербского, хорватского и английского языков. Так, доц. Павел Крейчи рассказал о некоторых чешских и сербохорватских фразах с топонимической составляющей; доц. Катарина Митричевич-Штепанек рассмотрела аугментативы как средство эвфемизации на примерах сербских и чешских переводных эквивалентов с английского языка; маг. Доминика Кубишова проанализировала дискурс инаугурационных речей избранных президентов; маг. Шимон Тесар говорил о чешских диалектах.

Некоторые выступающие подготовили сообщения, затрагивающие довольно узкие, но от этого не менее интересные области искусства. Например, д-р. Павел Пилх рассказал о сербских комиксах, а доц. Зузана Чижикова - о чешском экспериментальном творчестве в земляческом журнале «Nový život», издаваемом в 7о-ые и 8о-ые годы XX века в Сербии на словацком языке.

Приятным и символичным моментом коллоквиума было то, что четвертый блок, доклады в котором касались в основном сферы литературы, проходил в библиотеке кафедры славистики филологического факультета Белградского университета это создавало определенную теплую атмосферу. Два доклада в этом заключительном блоке были посвящены украинской культуре: д-р. Таня Гаев говорила об украинской поэтессе Лесе Украинке, а д-р. Петр Калина - об украинских композиторах в Пражской консерватории. Русская литература тоже не была оставлена в стороне: д-р. Анна Агапова продемонстрировала доклад «Константин Вагинов в Чехословакии», а д-р. Анна Яковлевич Радунович - «Женское образование как циклообразующий фактор в „Домашних разговорах“ В. Ф. Одоевского».

Сотрудники и аспиранты Университета им. Масарика приятно и полезно провели время не только в течение самого коллоквиума, но также и во время прогулок по Белграду, Земуну и Нови-Саду. Следует также отметить то гостеприимство, с которым коллеги из Сербии встретили участников коллоквиума. Несомненно то, что эта культурная поездка запомнится надолго, и в следующий раз Институт славистики философского факультета Университета им. Масарика ожидает коллег из Белграда уже в Брно, для проведения следующего коллоквиума, поддержания научного диалога и укрепления связей между славистами.

Юлия Алексеевна Дмитриева

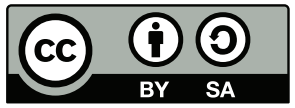

This work can be used in accordance with the Creative Commons BY-SA 4.0 International license terms and conditions (<https://creativecommons.org/licenses/by-sa/4.0/legalcode>). This does not apply to works or elements (such as images or photographs) that are used in the work under a contractual license or exception or limitation to relevant rights. 